ISSN: 2302-8556

\title{
Pengaruh Efektivitas Penggunaan Sistem Informasi Akuntansi, Budaya Kerja, dan Insentif terhadap Kinerja Karyawan
}

\author{
Astri Widhawati ${ }^{1}$ \\ I Gst.AyuEka Damayanthi ${ }^{2}$ \\ ${ }^{1}$ Fakultas Ekonomi dan Bisnis Universitas Udayana (Unud), Bali, Indonesia \\ email: astriwidhawati04@gmail.com/ telp: 087855479315 \\ ${ }^{2}$ Fakultas Ekonomi dan Bisnis Universitas Udayana (Unud), Bali, Indonesia
}

\begin{abstract}
ABSTRAK
Keberlangsungan dan keberhasilan suatu perusahaan atau organisasi dapat dilihat dari kinerja yang dimiliki oleh karyawan. Perusahaan atau organisasi mengharapkan karyawan dapat menyelesaikan tugas dan menghasilkan informasi secara tepat waktu, akurat, dan reliable. Perusahaan harus memperhatikan faktor-faktor yang dapat mempengaruhi kinerja karyawan.Penelitian ini bertujuan untuk mengetahui pengaruh efektivitas penggunaan sistem informasi akuntansi, budaya kerja, dan insentif terhadap kinerja karyawan. Penelitian ini dilakukan pada Bank Perkreditan Rakyat (BPR) di Kota Denpasar. Teknik penentuan sampel yang digunakan dalam penelitian ini adalah teknik purposive sampling. Responden dalam penelitian ini bagian pengawas intern, bagian kredit dan marketing, bagian dana, dan bagian accounting. Pengumpulan data dilakukan dengan cara penyebaran kuesioner dan wawancara.Teknik analisis data yang digunakan adalah analisis regresi linier berganda.Hasil penelitian ini menunjukkan bahwa efektivitas penggunaan sistem informasi akuntansi, budaya kerja, dan insentif berpengaruh positif dan signifikan terhadap kinerja karyawanpada BPR di Kota Denpasar.
\end{abstract}

Kata kunci:Efektivitas SIA, budaya, insentif, kinerja.

\begin{abstract}
Sustainability and success of a company or organization can be seen from the performance owned by employees. Companies or organizations expect employees to complete tasks and produce information in a timely, accurate, and reliable manner. This study aims to determine the effect of the effectiveness of the use of accounting information systems, work culture, and incentives on employee performance. This research was conducted at Rural Bank (BPR) in Denpasar City. Determination technique of sample used in this research is purposive sampling technique. Respondents in this study are the internal supervisors, the credit and marketing division, the funding section, and the accounting department. Data collection was done by distributing questionnaires and interviews. Data analysis technique used is multiple linear regression analysis. The results of this study indicate that the effectiveness of the use of accounting information systems, work culture, and incentives have a positive and significant impact on employee performance. Keywords:Effectiveness of SIA, culture, incentives, performance.
\end{abstract}




\section{PENDAHULUAN}

Bank Perkreditan Rakyat (BPR) adalah sebuah lembaga keuangan bank yang menerima simpanan hanya dalam bentuk deposito berjangka, tabungan, atau bentuk lainnya yang dipersamakan dengan itu serta menyalurkan dana sebagai usaha BPR. BPR merupakan pendukung perkembangan perekonomian Indonesia, terutama untuk kegiatan usaha mikro, kecil, dan menengah serta sektor informal. Menurut (Kasmir 2012:40) kegiatan BPR adalah menghimpun dana, memberikan kredit, menyediakan pembiayaan dan penempatan dana, menempatkan dananya dalam bentuk Sertifikat Bank Indonesia (SBI), deposito berjangka, sertifikat deposito, dan atau tabungan pada bank lain.

Penghimpunan dan penyaluran dana dari BPR seharusnya lebih tertuju pada kepentingan rakyat. (Yuniarti, 2011)menyatakan BPR seharusnya lebih dapat mengembangkan Usaha Mikro dan Menengah Kecil (UMKM). Keberadaan BPR bagi masyarakat daerah pedesaan diharapkan mampu menjadi ujung tombak dalam pembiayaan se UMKM (Lestari, 2014). Pengembangan UMKM dilakukan seluruh Kabupaten dan Kota di seluruh Indonesia. Salah satu kota yang bergiat mengembangkan UMKM adalah Kota Denpasar. Bahkan, dengan dorongan kepada UMKM tersebut lembaga International Council for Small Business (ICSB) Indonesia memberikan penghargaan untuk pemerintah Denpasar kategori "PolicyMaker". 
Penghargaan diterima Kadis Koperasi dan UMKM Kota Denpasar yang diserahkan Presiden ICSB Indonesia(Isarepok, 2017).Kondisi ini tentunya merupakan peluang tersendiri bagi BPR yang ada di Kota Denpasar. Peluang ini sebaiknya dapat disikapi oleh BPR dengan cara meningkatkan kinerjanya.

Kinerja adalah hasil kerja baik secara kualitas maupun kuantitas yang dicapai oleh seseorang dalam melaksanakan tugas sesuai tanggung jawab yang diberikan (Dewi, 2015). Kinerja karyawan dilihat dari hasil seorang karyawan dalam menyelesaikan pekerjaannya berdasarkan kemampuan yang dimiliki karyawan tersebut (Putra, 2016).Kinerja karyawan adalah faktor penting yang menentukan keberhasilan suatu organisasi (Sabir et al., 2012).

Sistem informasi akuntansi adalah komponen yang sangat penting bagi keberhasilan organisasi karena dapat meningkatkan efektivitas dan efisiensi berbagai proses organisasi, pengambilan keputusan dan kerjasama tim dalam organisasi(Williams and Sawyer, 2010:17). Sistem informasi berbasis komputer memiliki lima komponen yaitu input, proses, penyimpanan, output dan pengendalian internal dan berlaku di bawah kondisi kepastian, risiko dan ketidakpastian (Mollanazari and Abdolkarimi, 2012). Tanpa adanya teknologi yang mendukung, maka sistem informasi tidak akan menghasilkan informasi tepat waktu. 
Astri Widhawati dan I Gst. Ayu Eka Damayanthi. Pengaruh...

Sistem informasi yang digunakan dalam perusahaan adalah sistem informasi akuntansi. Sistem informasi memberi kesempatan bagi pebisnis untuk meningkatkan efesiensi dan efektivitas dalam pengambilan keputusan sehingga memungkinkan perusahaan memperoleh keunggulan kompetitif (Edison et al., 2012). Sistem informasi akuntansi adalah sistem yang dapat digunakan untuk mengolah transaksi keuangan sehingga menghasilkan informasi yang dapat digunakan dalam pengambilan keputusan (Dehghanzade et al., 2011).Sistem informasi akuntansi merupakan sistem yang mengolah data transaksi keuangan menjadi informasi keuangan (Awosejo et al., 2013).Salah satu faktor yang dianggap penting dalam keberhasilan suatu organisasi terutama dalam pengambilan keputusan adalah sistem informasi akuntansi yang diimplementasikan dengan baik (Al-Eqab, 2013).

Efektivitas penggunaan sistem informasi akuntansi pada perusahaan atau bank tergantung pada kemampuan teknik yang dimiliki pemakai sistem informasi akuntansi karena kemampuan teknik sangat mempengaruhi kinerja pemakainya (Putra, 2016). Keberhasilan efektivitas penggunaan sistem informasi akuntansi pada perusahaan berhubungan erat dengan sumber daya manusia. Efektivitas suatu sistem dilihat dari kontribusinya dalam pembuatan keputusan, evaluasi kinerja, kualitas informasi serta pengendalian internal dari transaksi perusahaanm(Sajady et al., 2008).Putra (2016) danDewi (2015) menunjukan bahwa efektivitas penggunaan SIA berpengaruh positif dan signifikan terhadap kinerja karyawan. 
Budaya kerja yang ada dalam suatu organisasi merupakan sarana dalam membangun sikap dan perilaku anggota organisasi agar dapat mendukung produktivitas kerja serta mampu menghadapi berbagai tantangan yang akan datang. (Pinhoet al., 2014) mengatakan budaya adalah suatu nilai dan interpretasi anggota organisasi. Budaya kerja berperan penting dalam menciptakan kebiasaan dalam suatu organisasi (Joseph and Francis 2015). Persoalan yang mendasar bagi perusahaan atau organisasi adalah menciptakan budaya kuat dengan kata lain bagaimana mengubah budaya lemah menjadi budaya kuat yang pada akhirnya akan mampu meningkatkan kinerja karyawan untuk tercapainya tujuan dari perusahaan atau organisasi (Silvia, 2016). Budaya yang kuat akan berpengaruh positif pada perilaku kerja karena dapat memberikan motivasi luar biasa pada karyawan untuk mencapai kinerja yang maksimal.

Insentif umumnya dilakukan sebagai strategi untuk meningkatkan produktivitas dan efisiensi perusahaan dengan memanfaatkan perilaku pegawai yang mempunyai kecenderungan kemungkinan bekerja seadanya atau tidak optimal. Insentif yang diterima oleh karyawan merupakan salah satu hal yang harus diperhatikan perusahaan. Besar kecilnya insentif yang diterima karyawan dapat berpengaruh pada semangat kerja karyawan. Dengan adanya pemberian insentif yang tepat serta cara kerja yang baik sehingga ke depannya, proses kerja organisasi dapat berjalan sesuai tujuan organisasi (Dwijayanthi, 2013). 
Astri Widhawati dan I Gst. Ayu Eka Damayanthi. Pengaruh...

Besarnya peluang UMKM di Kota Denpasar ternyata belum mampu dimanfaatkan secara maksimal. Ini bukan hanya akibat dari persaingan dengan bank umum lainnya. Namun juga karena kinerja dari BPR di Kota Denpasar yang belum maksimal.Masalah kinerja operasional sistem yang kurang memadai dapat menyebabkan kerugian karena adanya kesalahan dan keterlambatan dalam pengambilan keputusan, berkurangnya kepercayaan nasabah, dan lain-lain.

Berdasarkan hasil wawancara beberapa BPR di kota denpasar diketahui bahwa ada beberapa fenomena masalah yang sering dihadapi adalah keterlambatan pembuatan laporan kepada Bank Indonesia. Keterlambatan ini disebabkan oleh karena kurang cepatnya pendistribusian arus informasi yang dibutuhkan, karena sistem pengolahan data pada BPR belum teratur, contohnya keterlambatan pembayaran angsuran kredit setiap bulannya tidak dapat diperoleh dengan cepat karena sistem pengarsipan kurang menunjang. Selain itu pada BPR ini banyak sekali data yang tersebar dan sistem pengarsipan datanya tidak baik, sehingga seringkali timbul kesulitan untuk mendapatkan data dan informasi yang dibutuhkan.

Sistem informasi akuntansi yang digunakan di BPR kota Denpasar yaitu Standar Akuntansi Keuangan Entitas Tanpa Akuntabilitas Publik atau lebih dikenal dengan (SAK ETAP) dan Assist-BPR.Net. SAK ETAP bertujuan untuk menciptakan fleksibilitas dalam penerapannya dan diharapkan memberi kemudahan akses ETAP kepada pendanaan dari perbankan. 
Assist-BPR.Net merupakan produk yang diperuntukkan untuk Bank Perkreditan Rakyat (BPR) yang memiliki peran dan posisi sebagai penopang utama roda ekonomi semakin terasa penting yang ditandai dengan meningkatnya kapasitas dan kapabilitas BPR dalam memberikan pelayanan kepada para nasabahnya.

Hasil-hasil penelitian yang dilakukan sebelumnya yaitu, Putra (2016), Sari (2008), dan Dewi (2015), menunjukan pengaruh positif efektivitas penggunaan SIA terhadap kinerja karyawan. Berbeda dengan penelitian Kouseret al.,(2011), Kharuddinet al.,(2010), Urquia et al., (2011)yang memperoleh hasil yang sebaliknya. Senada dengan Nejadhosseini and Corresponding (2012) yang juga menunjukan pengaruh negatif penerapan SIA terhadap kinerja tenaga kerja.

Beberapa fenomena masalah yang terjadi pada BPR sekarang ini, permasalahan tersebut yaitu masih ada karyawan yang tidak disiplin dalam waktu bekerja, masih ada karyawan yang terlambat ke kantor. Adanya beberapa karyawan yang istirahat tidak pada saat jam istirahat kantor masih berlangsung. Beberapa pegawai juga diketahui tidak disiplin seperti, adanya karyawan tidak terlihat di lapangan saat jam kerja masih berlangsung dan pulang kerja lebih awal. Kedisiplinan di dalam perusahaan dapat menurunkan kinerja, sehingga pekerjaan yang diberikan tidak akan selesai dengan tepat waktu dan karyawan juga tidak merasakan adanya tanggungjawab kepada pekerjaannya. 
Astri Widhawati dan I Gst. Ayu Eka Damayanthi. Pengaruh...

Kinerja karyawan haruslah berorientasi terhadap pembenahan budaya kerja, sehingga akan tercipta karyawan yang profesional. Sebelumnya beberapa penelitian mengenai pengaruh budaya kerja terhadap kinerja karyawan Silvia (2016), dan Situmorang dan Asmarazisa (2016)menunjukan budaya kerja berpengaruh positif terhadap kinerja karyawan.

Penelitian sebelumnya Dwijayanthi (2013), Verbeeten (2008),dan Dewi (2015) menunjukan insentif berpengaruh positif dan signifikan terhadap kinerja karyawan. Salah satu upaya dalam meningkatkan kinerja seseorang adalah melalui insentif yang diberikan untuk karyawan yang berhasil melaksanakan pekerjaannya dengan baikpermasalahan yang berkaitan dengan insentif, diantaranya insentif diberikan untuk memotivasi kinerja karyawan perusahaan yang sempat turun atau kurang produktif tidak sesuai target perusahaan. Kinerja karyawan pengguna sistem informasi akuntansi pada BPR di Kota Denpasar masih kurang optimal. Adanya kinerja yang kurang optimal ini dapat menurunkan produktivitas BPR.

Berdasarkan hasil uraian di atas, ini berarti peluang BPR di Kota Denpasar ternyata belum mampu dimanfaatkan secara maksimal. Ini bukan hanya akibat dari persaingan dengan bank umum lainnya. Namun juga karena kinerja dari BPR di Kota Denpasar yang belum maksimal. Adapun tujuan penelitian ini yaitu untuk mengetahui pengaruh efektivitas penggunaan SIA,budaya kerja, dan insentifterhadap kinerja karyawan pada BPR di Kota Denpasar. 
Hasil penelitian ini diharapkan dapat digunakan sebagai tambahan pengetahuan mengenai pengaruh efektivitas penggunaan sistem informasi akuntansi, budaya kerja, dan insentif terhadap kinerja karyawan pada BPR di Kota Denpasar. Hasil penelitian ini juga diharapkan dapat menjadi referensi serta memberikan sumbangan konseptual bagi penelitian selanjutnya.Hasil penelitian diharapkan dapat memberi masukan kepada BPR Kota Denpasar agar dapat lebih baik dalam pengelolaan sumber daya manusia terkait dengan kinerja dari karyawan pengguna sistem informasi akuntansi, membina budaya kerja yang baik, serta meningkatkan atau mempertahankan insentif yang diberikan dalam mencapai tujuan perusahaan.

Menurut Herzberg (1999) motivasi adalah "proses mempengaruhi atau mendorong pegawai untuk menyelesaikan pekerjaan yang dilakukan.Dalam kaitannya dengan kinerja karyawan, menurut Herzberg (1999) kinerja karyawan dalam motivasi adalah dorongan semangat kerja yang timbul dari dalam diri karyawan sehingga mau bekerja keras dengan memberikan semua kemampuan dan ketrampilan demi terwujudnya tujuan organisasi, motivasi tersebut dikelompokkan kedalam motivasi yang bersifat intrinsik dengan aspek, adanya komitmen untuk memajukan organisasi, bekerja dengan berdisiplin tinggi, memiliki semangat dan tanggung jawab penuh dalam bekerja, memiliki sikap dan kepribadian yang baik, selalu termotivasi untuk mengeluarkan ide atau gagasan yang berkaitan dalam penyelesaian tugas kantor, tercapainya target dalam bekerja. 
Putra (2016) menggunakan model TPC (Technology to Performance Chain) yang dikembangkan oleh Goodhue yang mencoba keberhasilan "teknologi sistem informasi" yang diterapkan dalam organisasi atau perusahaan dengan menggunakan evaluasi pemakai. Efektivitas berkaitan dengan relevansi suatu informasi dalam mendukung suatu proses bisnis, termasuk di dalamnya harus disajikan dalam waktu yang tepat, akurat, konsisten, dapat digunakan dan lengkap.Putra (2016) menyatakan efektivitas penggunaanSIAberpengaruh secara positif terhadap kinerja karyawan. Penelitian olehWirawan (2016) dan Sari (2008)juga memperoleh hasil dimana efektivitas penggunaan sistem penggunaan SIA berpengaruh positif terhadap kinerja individual. Berdasarkan uraian tersebut maka hipotesis pertama dalam penelitian ini yaitu:

$\mathrm{H}_{1}$ : Efektivitas penggunaan sistem informasi akuntansi berpengaruh positif terhadap kinerja karyawan pada BPR di Kota Denpasar.

Budaya kerja karyawan adalah suatu sikap dan prilaku karyawan dalam melaksanakan pekerjaan sehari-hari yang berlangsung terus menerus sehingga menjadi suatu kebiasaan yang pada gilirannya akan membentuk karakter seorang karyawan dalam menangani setiap pekerjaannya agar tujuan organisasi dapat tercapai.Teori StrongCulture mengungkapkan adanya budaya organisasi yang baik dapat meningkatkan kinerja jangka panjang perusahaan. Penelitian oleh Silvia (2016) menyatakan bahwa budaya kerja berpengaruh positif terhadap kinerja karyawan. Menurut Situmorang dan Asmarazisa (2016)menyatakan bahwa budaya kerja berpengaruh positif terhadap kinerja karyawanpada PT. Bank 
Permata Batam. Berdasarkan uraian dan hasil penelitian sebelumnya di atas, dapat dirumuskan hipotesis sebagai berikut:

$\mathrm{H}_{2}$ : Budaya kerja berpengaruh positif terhadap kinerja karyawan pada BPR di Kota Denpasar.

MenurutMangkunegara (2007) insentif merupakan penghargaan yang diberikan dalam bentuk uang kepada karyawan dengan tujuan agar karyawan lebih termotivasi dalam bekerja mencapai tujuan organisasi. Berdasarkan teori harapan, motivasi kerja seseorang untuk dapat melaksanakan pekerjaannya dengan lebih baik tergantung dari hubungan timbal balik yang diperoleh dari hasil pekerjaannya. Insentif yang diterima oleh karyawan merupakan salah satu hal yang harus diperhatikan perusahaan. Besar kecilnya insentif yang diterima karyawan dapat berpengaruh pada semangat kerja karyawan. Penelitian Dwijayanthi (2013)menyatakan adanya pengaruh positif insentif terhadap kinerja karyawan pada SKPD Dispenda Pemerintah Kota Denpasar. Penelitian olehDewi (2015)menunjukkan hasil adanya pengaruh positif insentif terhadap kinerja karyawan pada LPD di Kota Denpasar. Berdasarkan uraian diatas, hipotesis yang diajukan yaitu:

$\mathrm{H}_{3}$ : Insentif berpengaruh positif terhadap kinerja karyawan padaBPR di Kota Denpasar. 


\section{METODE PENELITIAN}

Penelitian ini menggunakan pendekatan kuantitatif berbentuk asosiatif. Menurut Sugiyono (2014) penelitian asosiatif adalah penelitian yang dilakukan dengan tujuan mengetahui hubungan antara dua variabel atau lebih. Penelitian ini membahas pengaruh efektivitas penggunaan sistem informasi akuntansi, budaya kerja dan insentif terhadap kinerja karyawan pada BPR di Kota Denpasar. Desain Penelitian dapat diperhatikan pada Gambar 1.

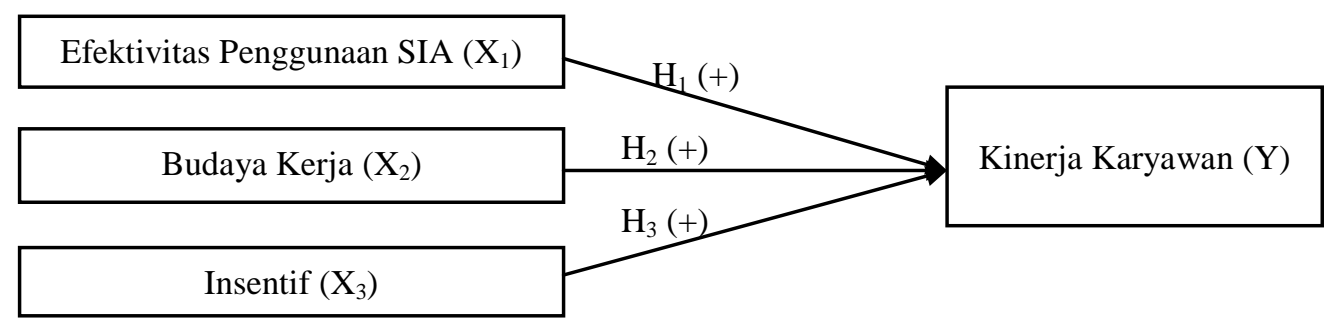

\section{Gambar 1.}

\section{Desain Penelitian}

Penelitian ini dilakukan pada tiap BPR di Kota Denpasar yang telah menggunakan atau menerapkan SIA.Objek penelitian adalah suatu sifat atau atribut yang ditetapkanpeneliti untuk dipelajari dan kemudian diambil kesimpulan. Objek penelitian ini adalah kinerja karyawan pada BPR di Kota Denpasar yang dipengaruhi oleh efektivitas penggunaan SIA, budaya kerja, dan insentif.

Variabel independen atau variabel bebas dalam penelitian ini adalah efektivitas penggunaan sistem informasi akuntansi $\left(\mathrm{X}_{1}\right)$, budaya kerja $\left(\mathrm{X}_{2}\right)$, dan insentif $\left(\mathrm{X}_{3}\right)$.Efektivitas penggunaan sistem informasi akuntansi dapat dilihat dari kemudahan pengguna sistem informasi akuntansi dalam melakukan pengolahan data perusahaan. MenurutPutra(2016) indikator yang digunakan untuk mengukur 
efektivitas penggunaan SIA ada 4 (empat) yaitu mudah dalam pengoperasian, mudah dalam memberikan penilaian, memiliki kemampuan dalam menggunakan SIA, memiliki kemampuan berbahasa asing.

Budaya kerja adalah suatu nilai-nilai yang dijadikan pedoman dalam bertingkah laku para karyawan dalam berorganisasi di lingkungan kerja seharihari. Suatu pendekatan yang didasari pada suatu kebijakan keputusan dari perusahaan dalam upaya peningkatan kinerja karyawan dapat dilakukan dengan studi tentang budaya kerja. Usaha penilaian terhadap nilai-nilai budaya kerja memiliki hubungan yang nyata dengan kinerja karyawan yang diharapkan mampu mendorong karyawan untuk melaksanakan tugas dan tanggung jawab pekerjaan secara baik dan benar. Indikator yang digunakan untuk mengukur budaya kerja menurut Veriana (2016) yaitu bertanggung jawab dalam mengemban amanah, kompeten menangani tugas dan pekerjaan, inovasi, kerjasama.

Insentif adalah kompensasi yang diberikan berkaitan dengan produktivitas. Cara pengukuran dari insentif menurut Dwijayanthi (2013)yaitu penghargaan atas prestasi yang dicapai, insentif berupa uang tunai atau sertifikat, insentif yang diberikan sudah adil, insentif yang diterima sudah memenuhi kebutuhan karyawan, insentif yang diterima sudah sesuai dengan beban kerja, insentif yang diterima dapat memicu kinerja. 
Astri Widhawati dan I Gst. Ayu Eka Damayanthi. Pengaruh...

Variabel dependen atau variabel terikat dalam penelitian ini adalah kinerja karyawan (Y).Indikator pengukuranvariabel kinerja karyawan yang digunakan dalam penelitian ini diadopsi dari penelitian Putra (2016) yaituefektivitas dan efisiensi, produktivitas, kuantitas kerja, kualitas kerja. Variabel-variabel dalam penelitian ini diukur dengan menggunakan skala likert empat poin, yaitu skor $1=$ sangat tidak setuju (STS), skor 2 = tidak setuju (TS), skor $3=$ setuju (S), dan skor 4 = sangat setuju (SS).

Jenis data kuantitatif dalam penelitian ini adalah skor jawaban kuesioner yang telah diisi oleh responden.Jenis data kualitatif dalam penelitian ini adalah daftarBPR yang terdapat di Kota Denpasar.Berdasarkan sumbernya, data primer dalam penelitian ini diperoleh berupa jawaban-jawaban dari kuesioner yang telah disebarkan kepada responden di BPR Kota Denpasar.Data sekunder dalam penelitian ini adalah mengenai daftar BPR di Kota Denpasar.Teknik pengumpulan data dalam penelitian ini adalah wawancara dan kuesioner yang disebarkan langsung kepada sasaran responden ke setiap BPR yang telah ditentukan.

Populasi dalam penelitian ini adalah seluruh karyawan BPR di Kota Denpasar yang menggunakan sistem informasi akuntansi dalam penyelesaian tugas-tugas. Berdasarkan hasil wawancara dan penyebaran kuesioner jumlah karyawan yang menggunakan sistem informasi di BPR Kota Denpasar adalah 400 karyawan. 
Metode penentuan sampel yang digunakan dalam penelitian ini adalah metode purposive sampling yang merupakan teknik penentuan sampel dengan kriteria tertentu, untuk memperoleh sampel yang relevan terhadap penelitian. Kriteria dalam pengambilan sampel dalam penelitian ini yaitu karyawan yang bekerja lebih dari 1 tahun, karyawan yang menggunakan sistem informasi akuntansi, dan karyawan yang menerima insentif di BPR Kota Denpasar.Berdasarkan perhitungan sampel yang dilakukan, maka jumlah sampel dalam penelitian ini sebanyak 75 responden.

Teknik analisis data yang digunakan adalah analisis regresi linier berganda yang merupakan pengujian yang dilakukan untuk mengetahui ada atau tidaknya pengaruh antara dua variabel yaitu variabel bebas dengan variabel terikat. Pengujian ini dilakukan dengan menggunakan bantuan program Statistical Product and Service Solution. Hasil analisis dinyatakan dalam bentuk persamaan regresi linier sebagai berikut (Sugiyono, 2017:277):

$Y=a+\beta_{1} X_{1}+\beta_{2} X_{2}+\beta_{3} X_{3}+\varepsilon$

Keterangan:

$\mathrm{Y}=$ Variabel kinerja karyawan

$\mathrm{a}=$ Konstanta atau titik perpotongan dengan sumbu $\mathrm{y}$, bila $\mathrm{x}=0$

$\mathrm{X}_{1}=$ Variabel efektivitas penggunaan sistem informasi akuntansi

$\mathrm{X}_{2}=$ Variabel budaya kerja

$\mathrm{X}_{3}=$ Variabel Insentif

$\beta_{1}=$ Koefisien regresi efektivitas penggunaan SIA

$\beta_{2}=$ Koefisien budaya kerja

$\beta_{3}=$ Koefisien Insentif

$\varepsilon=$ Komponen pengganggu 


\section{HASIL DAN PEMBAHASAN}

Uji validitas merupakan pengujian instrumen penelitian sebagai suatu derajat ketepatan alat ukur penelitian tentang inti atau arti sebenarnya yang diukur. Tinggi rendahnya validitas menunjukkan sejauh mana data yang terkumpul tidak menyimpang dari gambaran tentang variabel yang dimaksud. Berdasarkan hasil uji validitas dapat disimpulkan bahwa instrumen penelitian yang terdiri dari itemitem pernyataan efektivitas penggunaan SIA $\left(\mathrm{X}_{1}\right)$, budaya Kerja $\left(\mathrm{X}_{2}\right)$, insentif $\left(\mathrm{X}_{3}\right)$, dan kinerja karyawan $(\mathrm{Y})$ memiliki nilai koefisien korelasi yang lebih besar dari 0,30 seluruh indikator pernyataan tersebut telah memenuhi syarat validitas data.

Reliabilitas adalah derajat ketepatan, ketelitian atau keakuratan yang ditunjukkan oleh instrumen pengukuran dimana pengujiannya dapat dilakukan secara internal, yaitu pengujian dengan menganalisis konsistensi butir-butir pertanyaan yang ada. Suatu instrumen dikatakan reliabel, jika instrumen tersebut memiliki nilai Alpha Cronbach lebih dari 0,60.

Hasil uji reliabilitas menunjukkan bahwa seluruh instrumen penelitian yaitu Efektivitas Penggunaan Sistem Informasi Akuntansi, Budaya Kerja, Insentif, dan Kinerja karyawan memiliki koefisien Cronbach's Alpha lebih dari 0,60. Hal ini berarti dapat dikatakan bahwa semua instrumen reliabel sehingga dapat digunakan untuk melakukan penelitian.

Uji asumsi klasik dalam penelitian ini dilakukan untuk memastikan hasil yang diperoleh memenuhi asumsi dasar dalam analisis regresi. Hasil uji asumsi 
klasik yang dilakukan dalam penelitian ini yaitu uji normalitas, uji multikolinieritas, dan uji heteroskedastisitas. Uji normalitas bertujuan untuk mengetahui apakah residual dari model regresi yang dibuat berdistribusi normal atau tidak. Untuk menguji apakah data yang digunakan normal atau tidak dapat dilakukan dengan menggunakan uji Kolmogorov Sminarnow. Apabila koefisien Asymp. Sig. (2-tailed) lebih besar dari 0,05 maka data tersebut dikatakan berdistribusi normal. Berdasarkan hasil uji normalitas pada penelitian ini diperoleh nilai Kolmogorov-Smirnov (K-S) sebesar 0,918, sedangkan nilai Asymp.Sig. (2-tailed) sebesar 0,368. Hasil tersebut mengindikasikan bahwa model persamaan regresi tersebut berdistribusi normal karena nilai Asymp.Sig. (2-tailed) 0,368 lebih besar dari nilai alpha 0,05 .

Uji multikolinearitas bertujuan untuk menguji apakah model regresi ditemukan adanya korelasi antara variabel bebas.Model regresi yang baik seharusnya tidak terjadi korelasi di antara variabel bebas. Hasil uji multikolinearitas pada penelitian ini diperoleh nilai tolerance dan VIF dari variabel efektivitas penggunaan sistem informasi akuntansi, budaya kerja, dan insentif. Nilai tersebut menunjukkan bahwa nilai tolerance untuk setiap variabel lebih besar dari 0,10 dan Variance Factor (VIF) lebih kecil dari 10 yang berarti model persamaan regresi bebas dari multikolinearitas.

Uji heteroskedastisitas bertujuan untuk menguji apakah model regresi terjadi ketidaksamaan varians dari residual satu pengamatan kepengamatan yang lainnya. Model regresi dikatakan baik adalah model regresi yang bebas dari 
Astri Widhawati dan I Gst. Ayu Eka Damayanthi. Pengaruh...

heteroskedatisitas. Berdasarkan uji heteroskedastisitas dalam penelitian ini diperoleh nilai sig. dari variabel efektivitas penggunaan sistem informasi akuntansi, budaya kerja, dan insentif masing-masing sebesar 0,413, 0,371, dan 0,492. Nilai tersebut lebih besar dari 0,05 yang berarti tidak terdapat pengaruh anatara variabel bebas terhadap absolute residual. Dengan demikian, model yang dibuat tidak mengandung gejala heteroskedastisitas. Berdasarkan hasil uji normalitas, uji multikolinearitas dan uji heteroskedastisitas yang diperoleh pada penelitian ini maka dapat dinyatakan bahwa model regresi penelitian ini telah lolos uji asumsi klasik.

Tabel 1.

Statistik Deskriptif

\begin{tabular}{lccccc}
\hline & N & Minimum & Maximum & Mean & $\begin{array}{c}\text { Std. } \\
\text { Deviation }\end{array}$ \\
\hline Efektivitas Penggunaan SIA & & & & & \\
(X1) & 75 & 12 & 20 & 16,20 & 1,860 \\
Budaya Kerja (X2) & 75 & 24 & 32 & 30,01 & 2,089 \\
Insentif (X3) & 75 & 19 & 28 & 23,01 & 2,310 \\
Kinerja Karyawan (Y) & 75 & 20 & 36 & 29,68 & 3,390 \\
Valid N (listwise) & 75 & & & & \\
\hline
\end{tabular}

Sumber: Data diolah, 2018

Berdasarkan Tabel 1. dapat disimpulkan bahwa variabel efektivitas penggunaan SIA memiliki nilai rata-rata sebesar 16,2 menunjukkan bahwa respon responden dalam menjawab pertanyaan kuesioner cenderung merasa setuju pada masing-masing item pertanyaan artinya efektivitas penggunaan SIA cenderung tinggi. Variabel budaya kerja memilikinilai rata-rata sebesar 30,01 menunjukkan bahwa respon responden dalam menjawab pertanyaan kuesioner cenderung 
merasa setuju pada masing-masing item pertanyaan artinya budaya kerja cenderung tinggi.Variabel insentif memiliki nilai rata-rata sebesar 23,01 menunjukkan bahwa respon responden dalam menjawab pertanyaan kuesioner kurang merasasetuju pada masing-masing item pertanyaan artinya insentif cenderung rendah.

Analisis regresi linear berganda dilakukan untuk mengetahui besarnya pengaruh Efektivitas Penggunaan Sistem Informasi Akuntansi $\left(\mathrm{X}_{1}\right)$, Budaya Kerja $\left(\mathrm{X}_{2}\right)$ Insentif $\left(\mathrm{X}_{3}\right)$, dan Kinerja Karyawan $(\mathrm{Y})$. Hasil uji regresi linear berganda seperti yang disajikan pada Tabel 2.

Tabel 2.

Hasil Uji Regresi Linear Berganda

\begin{tabular}{|c|c|c|c|c|c|}
\hline \multirow[t]{2}{*}{ Model } & \multicolumn{2}{|c|}{$\begin{array}{l}\text { Unstandardized } \\
\text { Coefficients }\end{array}$} & \multirow{2}{*}{$\begin{array}{c}\begin{array}{c}\text { Standardized } \\
\text { Coefficients }\end{array} \\
\text { Beta }\end{array}$} & \multirow[t]{2}{*}{$\mathbf{T}$} & \multirow[t]{2}{*}{ Sig } \\
\hline & $\mathbf{B}$ & Std.Error & & & \\
\hline (Constant) & $-0,559$ & 5,751 & & $-0,097$ & 0,923 \\
\hline \multicolumn{6}{|c|}{ Efektivitas Penggunaan } \\
\hline SIA & 0,561 & 0,213 & 0,308 & 2,634 & 0,010 \\
\hline Budaya Kerja & 0,336 & 0,154 & 0,207 & 2,186 & 0,032 \\
\hline Insentif & 0,48 & 0,171 & 0,327 & 2,802 & 0,007 \\
\hline R Square & & & 0,362 & & \\
\hline F hitung & & & 13,409 & & \\
\hline Sig. F & & & 0 & & \\
\hline
\end{tabular}

Sumber: Data diolah, 2018

Koefisien determinasi $\left(\mathrm{R}^{2}\right)$ pada intinya adalah untuk mengukur seberapa jauh kemampuan model dalam menerangkan variasi variabel dependen. Nilai Adjusted $\mathrm{R}^{2}$ sebesar 0,335 mempunyai arti bahwa sebesar 33,5 persen variasi kinerja karyawan dipengaruhi oleh variansi efektivitas penggunaan sistem informasi akuntansi $\left(\mathrm{X}_{1}\right)$, budaya kerja $\left(\mathrm{X}_{2}\right)$, dan insentif $\left(\mathrm{X}_{3}\right)$, sedangkan sisanya 
ditentukan oleh faktor lain sebesar 66,5 persen.Pengujian model Fit (kelayakan model) dilakukan dengan uji F. Uji ini untuk mengetahui apakah semua variabel bebas secara bersama-sama mempengaruhi variabel terikat.Hasil uji Anova atau (F test) menunjukkan nilai $\mathrm{F}$ hitung sebesar 13,409 dengan signifikansi 0,000 yang probitabilitas signifikan lebih kecil dari alpha 0,05. Ini menunjukkan model yang digunakan dalam penelitian ini adalah layak.

Berdasarkan hasil analisis pengaruh efektivitas penggunaan SIA terhadap kinerja karyawan diperoleh nilai sig.t sebesar 0,010 dengan nilai koefisien beta 0,561. Nilai sig. t $0,010<0,05$ mengindikasikan bahwa $\mathrm{H}_{0}$ ditolak dan $\mathrm{H}_{1}$ diterima. Hal ini berarti adanya pengaruh antara efektivitas penggunaan SIA dengan kinerja karyawan, bahwa seorang karyawan dengan efektivitas menggunakan SIAyang baik maka kinerjanya akan meningkat.Sistem informasi akuntansi membantu penggunanya dalam menghasilkan informasi yang dapat digunakan dalam pengambilan keputusan. Sistem informasi akuntansi juga dapat membuat penggunanya bekerja dengan lebih efisien. Pengimplementasian sistem informasi yang tepat dapat memudahkan penggunanya dalam melakukan pengolahan data dan menyediakan informasi bagi perusahaan.

Penelitian ini didukung oleh teori Technology-to-Performance Chain(TPC). Model rantai TPC merupakan model yang menyatakan dimana teknologi akan memberikan dampak pada kinerja sesuai dengan kemampuan individu pengguna teknologi tersebut. Teknologi yang digunakan harus sesuai dengan tugas yang ada agar berdampak positif pada kinerja. Hasil penelitian ini 
ISSN: 2302-8556

E-Jurnal Akuntansi Universitas Udayana

Vol.24.2.Agustus (2018): 1301-1327

sesuai dengan penelitian yang dilakukan sebelumnya oleh Putra (2016) menunjukkan hasil bahwa efektivitas penggunaan SIA berpengaruh positif terhadap kinerja karyawan. Selain penelitian tersebut, penelitian ini juga sejalan dengan penelitian yang dilakukan olehSari (2008) menunjukkan hasil bahwa efektivitas penggunaan SIA berpengaruh positif terhadap kinerja individual.

Berdasarkan hasil uji hipotesis (Uji t)analisis pengaruh budaya kerja terhadap kinerja karyawan diperoleh nilai sig.t sebesar 0,032 dengan nilai koefisien beta 0,336 . Nilai sig. $\mathrm{t} 0,032<0,05$ mengindikasikan bahwa $\mathrm{H}_{0}$ ditolak dan $\mathrm{H}_{2}$ diterima. Hasil ini mempunyai arti bahwa budaya kerja berpengaruh positif dan signifikan terhadap kinerja karyawan sehingga hipotesis kedua dalam penelitian ini diterima.Pengaruh budaya kerja dapat menciptakan situasi yang dapat mendorong karyawan agar meningkatkan kinerja yang dimiliki.Karena dengan adanya budaya kerja yang baik dan terarah maka karyawan dapat menjalankan pekerjaan dengan runtun hasil yang maksimal.

Penelitian ini didukung oleh teori Strong Culture yang menyatakan adanya budaya yang kuat pada organisasi dapat berdampak pada peningkatan kinerja jangka panjang perusahaan. Adanya budayayang kuat pada organisasi dapat menciptakan penyesuaian tujuan antar anggota organisasi perusahaan.Hasil penelitian ini sesuai dengan penelitian yang dilakukan sebelumnya oleh Silvia (2016) menyatakan bahwa budaya kerja berpengaruh positif terhadap kinerja karyawan. Penelitian yang dilakukan oleh Situmorang dan Asmarazisa (2016) 
menyatakan bahwa budaya kerja berpengaruh positif terhadap kinerja karyawan pada PT. Bank Permata Batam.

Berdasarkan hasil uji hipotesis (Uji t)analisis pengaruh insentif terhadap kinerja karyawan diperoleh nilai sig.t sebesar 0,007 dengan nilai koefisien beta 0,480. Nilai sig. t $0,007<0,05$ mengindikasikan bahwa $\mathrm{H}_{0}$ ditolak dan $\mathrm{H}_{3}$ diterima. Hasil ini mempunyai arti bahwa insentif berpengaruh positif dan signifikan terhadap kinerja karyawan sehingga hipotesis ketiga dalam penelitian ini diterima.Hal ini menunjukkan bahwa dengan adanya insentif maka karyawan akan terus mencoba untuk lebih baik lagi dalam bekerja baik itu untuk karyawan sendiri maupun bagi perusahaan, mengingat adanya balas jasa dalam bentuk insentif yang diberikan perusahaan sesuai dengan hasil dan prestasi kerja yang dicapai.

Penelitian ini didukung oleh teori harapan yang menyatakan hal yang dapat memberikan motivasi pada seseorang untuk dapat bekerja lebih giat tergantung pada timbal balik yang diberikan dari pekerjaannya. Hasil penelitian ini sesuai dengan penelitian yang dilakukan sebelumnya oleh Dwijayanthi (2013)dan Dewi (2015) menyatakan bahwa insentif berpengaruh positif terhadap kinerja individu.

\section{SIMPULAN}

Berdasarkan pembahasan sebelumnya, maka dapat disimpulkan sebagai berikut:

1) Efektivitas penggunaan sistem informasi akuntansi berpengaruh positif terhadap kinerja karyawan pada BPR di Kota Denpasar. Hasil penelitian ini menunjukkan bahwa semakin tinggi tingkat efektivitas penggunaan sistem 
informasi akuntansi yang dimilki seseorang, maka cenderung akan meningkatkan kinerja karyawan; 2) Budaya kerja berpengaruh positif terhadap kinerja karyawan pada BPR di Kota Denpasar.

Hasil penelitian ini menunjukkan bahwa apabila semakin tinggi tingkat budaya kerja yang baikakan meningkatkan kinerja karyawan; 3) Insentif berpengaruh positif terhadap kinerja karyawan pada BPR di Kota Denpasar. Hasil penelitian ini menunjukkan bahwa peningkatan pemberian insentif yang diberikan, maka akan dapat meningkatkan potensi kinerja karyawan.

Berdasarkan hasil penelitian dan simpulan maka saran yang dapat diberikan bagi peneliti selanjutnyaketerbatasan dalam penelitian ini hendaknya dapat lebih disempurnakan lagi pada penelitian selanjutnya yaitu menambahkan variabel yang dapat mempengaruh kinerja karyawan. Penelitian selanjutnya sebaiknya dilakukan pada jenis perusahaan yang berbeda atau lokasi yang berbeda seperti BPR yang berada di Kabupaten Badung yang jumlahBPR-nya paling banyak sehingga persaingan akan semakin tinggi.

\section{REFERENSI}

Al-Eqab, Mahmoud and Dalia Adel. 2013. "The Impact of IT Sophistications on the Perceived Usefulness of Accounting Information Characteristics among Jordanian Listed Companies." College of Bussiness Adminstration Prince Sultan University Riyadh, Kingdome of Saudi Arabia Dalia 4(3):145-55.

Awosejo, O.J, Kekwaletswe, R, M, Pretorius, P and Zuva, T. 2013. "The Effect of Accounting Information Systems in Accounting." International Journal of Advanced Computer Research 1(2):21-31. 
Dehghanzade, Hamed, Mahammad Ali Moradi, and Mahvash Raghibi. 2011. "A Survey of Human Factors' Impacts on the Effectiveness of Accounting Information Systems." International Journal of Business Administration 2(4):166-75.

Dewi, Ni Made Utari Sintia. 2015. "Pengaruh Kemampuan Teknik Pemakai Sia, Partisipasi Manajemen, Insentif, Faktor Demografi Pada Kinerja Individu.” E-JUrnal Akuntansi Universitas Udayana 13(2):446-60.

Dr.Rehana Kouser. 2011. "Firm Size, Leverage And Profitability: Overriding Impact Of Accounting Information." Journal Of Management And Bussines Review 1(10):58-64.

Dwijayanthi, Diah Maha. 2013. "Pengaruh Insentif, Tingkat Pendidikan, Pelatihan Dan Pengalaman Kerja Terhadap Kinerja Individu Pengguna Sistem Informasi Akuntansi SKPD DISPENDA Kota Denpasar." E-Jurnal Akuntansi Universitas Udayana 4(2):332-44.

Edison, G., Manuere, F., Joseph, M., and Gutu, K. 2012. "Evaluation of Factors Influencing Adoption Of Accounting Information System By Small To Medium Enterprises In Chinhoyi." Journal of Contemporary Research in Bussiness 4(6):1126-41.

Grande, Urquia. 2011. "The Impact Of Accounting Information Systems (Ais) On Performance Measures: Empirical Evidence In Spanish Smes." The International Journal of Digital Accounting Research 11:1-25.

Herzberg. 1999. Teori Motivasi ke dua. Jakarta: Pustaka Indah.

Isarepok. 2017. Komitmen Dorong UMKM Denpasar Raih Penghargaan ICSB Indonesia.https://koperasi.denpasarkota.go.id/index.php/bacaberita/15927/Ko mitmen-Dorong-UMKM--Denpasar-Raih-Penghargaan-ICSB-Indonesia.

Diakses 12 November 2017.

Joseph, Owino O. dan Kibera Francis, (2015), “The Influence of Organizational Culture and Market Orientation on Performance of Microfinance Institutions in Kenya”, International Journal of Business and Management, Vol.10, No.8.

Kasmir. 2012. Bank Dan Lembaga Keuangan Lainnya. Jakarta: PT Raja Grafindo Persada.

Kharuddin, Saira. 2010. "Information System And Firms Performance: The Case Of Malaysian Small Medium Enterprises." International Bussines Research 3(4):28-35. 
Lestari, Murti. 2014. Dampak Krisis Ekonomi Dan Masuknya Bank Umum Pada Pasar Kredit Usaha Mikro Kecil Terhadap Kinerja Bank Perkreditan Rakyat (BPR) Diy. E-jurnal Keuangan dan Perbankan Universitas Kristen Duta Wacana. 18 (1). $45-63$.

Mollanazari, Mahnaz and Elahe Abdolkarimi. 2012. "The Effects of Task, Organization and Accounting Information Systems Characteristics on the Accounting Information Systems Performance in Tehran Stock Exchange." International Journal of Innovation, Management and Technology 3(4):44348.

Nejadhosseini, Siamak and Soudani Corresponding. 2012. "The Usefulness of an Accounting Information System for Effective Organizational Performance." School of Accounting and Management, Islamic Azad University U.A.E. Branch 4(5):136-45.

Pinho, Jose Carlos, (2014), "The role of corporate culture, market orientation and organisational commitment in organisational performance: The case of nonprofit organisations", Journal of Management Development, Vol.33 No.4, pp. 374-398.

Prab, Mangkunegara. A. A.Anwar. 2007. Manajemen Sumber Daya Manusia. Bandung: Cetakan Ke Tujuh PT. Remaja Rosdakarya.

Putra, I.Kadek Agastia Maha. 2016. "Agastia Maha. Pengaruh Efektivitas Penggunaan, Kepercayaan, Keahlian Pengguna, Dan Kualitas Sistem Informasi Akuntansi Terhadap Kinerja Karyawan Pada PT PLN (Persero) Distribusi Bali.” E-Jurnal Akuntansi Universitas Udayana 17(2):1516-45.

Robbins, P Stephen. 2000. Perilaku Organisasi Konsep,Kontroversi, Aplikasi. edisi.8, Jilid 1.Prenhalindo Jakarta.

Sabir,M Suleman, Jam Javed Iqbal, Kasif ur Rehman, Kamran Ali Shah \& M. Yameen. 2012. Impact of Corporate Ethical Vaulues on Ethical leadership and Employee Performance. Journal of business and social science,3(2): pp: 163-171.

Sajady, H., M. Dastgir, and H.Hashem Nejad. 2008. "Evaluation of the Effectiveness of Accounting Information Systems." International Journal of Information Science and Technology 6(2):49-59. 
Sari, Maria M.Ratna. 2008. "Pengaruh Efektivitas Penggunaan Dan Kepercayaan Terhadap Teknologi Sistem Informasi Akuntansi Terhadap Kinerja Individual Pada Pasar Swalayan Di Kota Denpasar." E-Jurnal Akuntansi Universitas Udayana 4(1).

Siagian, S.P. (1992). Organisasi Kepemimpinan \& Perilaku Administrasi. Jakarta: Rineka Cipta.

Silvia, I Wayan Bagia, Wayan Cipta. 2016. "Pengaruh Kompetensi Dan Budaya Kerja Terhadap Kinerja Karyawan.” E-Journal Bisma Universitas Pendidikan Ganesha 4(1).

Situmorang, Meyda Ruliani Theresia dan Asmarazisa Dhenny. 2016. Pengaruh Budaya Kerja Dan Pemberian Insentif Terhadap Kinerja Karyawan Pada Pt. Bank Permata Batam. E-jurnal Manajemen Universitas Riau Kepulauan, Batam, Indonesia. 3 (1). 98 - 109.

Sugiyono. 2017. "Metode Penelitian Pendidikan (Pendekatan Kuantitatif, Kualitatif, Dan R\&D)."

Verbeeten, Frank H. M. 2008. "Performance Management Practices in Public Sector Organizations." Accounting, Auditing \& Accountability Journal 21(3):427-54.

Veriana, Putu Ayu Agnes. 2016. "Pengaruh Efektivitas Penerapan Sistem Informasi Akuntansi, Budaya Organisasi Dan Kesesuaian Tugas Pada Kinerja Karyawan." E-Jurnal Akuntansi Universitas Udayana Fakultas Ekonomi Dan Bisnis Universitas Udayana (Unud) 17(3):2225-52.

Williams, Brian K. and Stacey C. Sawyer. 2010. "Using Information Technology: A Practical Introduction to Computers \& Communications New York, NY : McGraw-Hill.

Wirawan, Bima Satya.2016."Pengaruh Efektivitas Penggunaan Sistem Informasi Akuntansi Berbasis Teknologi Informasi, Kepercayaan, Kemampuan Teknik Personal, Dan Dukungan Manajemen Terhadap Kinerja Individual Bank Perkreditan Rakyat di Kabupaten Badung." Skripsi Akuntansi Universitas Udayana Fakultas Ekonomi Dan Bisnis Universitas Udayana. 
ISSN: 2302-8556

E-Jurnal Akuntansi Universitas Udayana Vol.24.2.Agustus (2018): 1301-1327

Yuniarti, Sari. 2011. Strategi Adaptif Bank Perkreditan Rakyat Dalam Menghadapi Ekspansi Kredit Umkm Bank Umum Di Malang. E-jurnal Keuangan dan Perbankan Universitas Merdeka Malang. 15 (3).437 - 445. 